Binghamton University

The Open Repository @ Binghamton (The ORB)

\title{
Futurism in Venezuela: Arturo Uslar Pietri and the Reviews Indice and válvula
}

Giovanna Montenegro

gmontene@binghamton.edu

Follow this and additional works at: https://orb.binghamton.edu/comparative_literature_fac

Part of the Comparative Literature Commons, Italian Literature Commons, Latin American Languages and Societies Commons, Modern Literature Commons, and the Theory and Criticism Commons

\section{Recommended Citation}

"Futurism in Venezuela: Arturo Uslar Pietri and the Reviews Indice and válvula." In Günter Berghaus, Ed. International Yearbook of Futurism Studies. Berlin: De Gruyter, 2012.

This Article is brought to you for free and open access by the Comparative Literature at The Open Repository @ Binghamton (The ORB). It has been accepted for inclusion in Comparative Literature Faculty Scholarship by an authorized administrator of The Open Repository @ Binghamton (The ORB). For more information, please contact ORB@binghamton.edu. 


\title{
International Yearbook of Futurism Studies
}

\author{
Edited by \\ Günter Berghaus \\ Editorial Board \\ Matteo D'Ambrosio · Marjorie Perloff \\ Irina Subotić · Jorge Schwartz \\ Contributing Editors
}

Emilia David · Matteo Fochessati · Rubén Gallo · Roger Griffin Benedikt Hjartarson · Chris Michaelides · Przemysław Strożek

Pierantonio Zanotti

Volume $2 \cdot 2012$

Open Issue

De Gruyter 


\section{Table of Contents}

Editorial

Section 1:

Critical responses to exhibitions, conferences and publications

Giorgio Di Genova: Nuovi archivi del futurismo . . . . . . . . . . 3

Günter Berghaus: Růžena Zátková: An 'atypical' Futurist . . . . . . . . 7

Günter Berghaus: Plurilinguism and the Avant-gardes . . . . . . . . . 14

Teresa Prudente: Futurism in the "Modernist Journals Project" . . . . . 20

Karoly Kokai: Viennese Futurism . . . . . . . . . . . . . . . . 25

Section 2:

Country Surveys

Pierantonio Zanotti

What is Miraiha? Academic Discourses on Japanese Futurism . . . . . . 35

ISSN (Print) 2192-0281

ISSN (Internet) 2192-029X

Library of Congress Cataloging-in-Publication Data

A CIP catalog record for this book has been applied for at the Library of Congress.

Bibliographic information publisbed by the Deutsche Nationalbibliotbele.

The Deutsche Nationalbibliothek lists this publication in the Deutsche Nationalbibliografie detailed bibliographic data are available in the Internet at http://dnb.d-nb.de.

(C) 2012 Walter de Gruyter GmbH \& Co. KG, Berlin/Boston

Printing: Hubert \& Co. GmbH \& Co. KG, Göttingen

$\infty$ Printed on acid-free paper

Printed in Germany

www.degruyter.com

Section 3:

Futurism Studies

\section{Matteo Fochessati}

Broom and Futurist Aristocracy: When the Futurist Movement

Met the Machine Age . . . . . . . . . . . . . . . . . . . . . . . . 69

Irene Chytraeus-Auerbach

Marinetti in Berlin

\section{Rubén Gallo}

Wireless Modernity: Mexican Estridentistas, Italian and Russian

Futurism . . . . ...................... 141 
Beata Śniecikowska

Poetic Experiments in Polish Futurism: Imitative, Eclectic

or Original?

Dominika Buchowska and Steven L. Wright

The Futurist Invasion of Great Britain, 1910-1914

Andrea Benedetti

The War Diaries of Filippo Tommaso Marinetti and Ernst Jünger . . 226

Tiit Hennoste

Ethno-Futurism in Estonia

Giovanna Montenegro

Futurism in Venezuela: Arturo Uslar Pietri and the Reviews

Indice and válvula.

Christopher Townsend

Henri-Martin Barzun's "Simultaneism" between the

Abbaye de Créteil and Futurism: The Individual and

the Crowd in late-Symbolist Art

Nikolai Sadik-Ogli

Finland and Futurism

Nina Parish

From Radio to the Internet: Italian Futurism, New Technologies

and the Persistence of the Book . .

Stefania Serafin

Russolo's Intonarumori: Musical Innovation at the Beginning

of the Twentieth Century

Section 4:

Bibliography

Günter Berghaus

A Bibliography of Publications on Futurism Published

in 2009-2011
Section 5:

Back Matter

List of Illustrations and Provenance Descriptions. . . . . . . . . . . 461

Notes on Contributors ............................ 465

Name Index . . . . . . . . . . . . . . . . . . . 473

Subject Index

Geographical Index . . . . . . . . . . . . . . . . 513 


\section{Futurism in Venezuela: Arturo Uslar Pietri and the Reviews Indice and válvula}

Giovanna Montenegro

The short-lived revue válvula, published in Caracas in 1928, was symbolic of the cursory invasion of Futurism into Venezuela, and of the fate of the avant-garde in that sory invas country betwe the 1920s a shake itself free from the patriarchal influence of the cafdillo Juan Vincente Góme (1857-1935), and was simultaneously on the eve of a shift from an agricultural to an oil-based economy, artistic avant-garde movements arrived in cultural centres such as Caracas and Maracaibo not with the boom and thunder appropriate to war-loving Futrism but rather, trickled in slowly, gradually changing the face of Venezuela futurs válvula, in its first and only issue in Janung literature. That being said, he ner 1928, carried the urgency and abrupt nature of Italian Futurism within its visual an editorial content. The main propagandist of the new Venezuelan avant-garde was the young Arturo Uslar Pietri (1906-2001) who eschewed labelling the new literary the young Arturo Fuvement Indice: Quincenario Futurist aesthetic in his frotura in 1927. However, his collaboration with the valuula de combate. Critica y literatura, in 1927. However, his collaboration with the valual group in 1928 would mark the transition
demand for aesthetic and social renewal.

Keywords: Futurism in Latin America, Venezuelan literature, Little Magazines, literary manifestos, criollismo, mestizaje

\section{Introduction: Futurism in Latin America and Venezuela}

The Chilean critic Nelson Osorio Tejeda, former director of the Centro de Estudios Latinoamericanos Rómulo Gallegos (CELARG), and author of El futurismo y la vanguardia literaria en América Latina, dates the emer gence of a Venezuelan avant-garde to the mid-1920s. ${ }^{1}$ Like other avant gence of a Venezuelan avant-garde to the mid-1920s. Like oth after the
garde movements in Argentina, Chile, Cuba, Mexico and Peru a

1 Osorio: El futurismo y la vanguardia en América Latina, p. 34. DOI $10.1515 /$ futur-2012.0016
First World War, the Venezuelan avant-garde was, in itself, a response to modernist aesthetics that permeated literary and artistic circles throughout the Americas. ${ }^{2}$ The emergence of these aesthetic vanguard movements in Latin America corresponded to certain socio-political deverements curring within the region. Hevelopments imes, as the meaning of the "vangua d" not arrive ahead of the imes, as the manng of the term "vanguard" would imply, but rather behind them. During his stay in France and England, Venezuelan writer José Gil Fortoul (1861-1943) pondered the time shift between European Modernism and the avant-garde in the Americas and asked himself: "I Modern $\left[\right.$ Modernist ${ }^{3}$ ] cycle coming to anericas and asked himself: "I the recent [Mere [on the AmeriConinent? It will pron here [in Europe] as trends end to travel at a sluggish pace". "Fortoul's question undersores as trends bersome nature of transatlantic travel that delayed cultural commodities (news, goods and ideas) between Europe and the Americas, and included everything from fashionable Parisian frocks to polemical Futurist manifestos. However, the concept of a "sluggish", one-sided, cultural exchange (always beginning in Europe and travelling to the Americas) various Latin American identities of Futuris the North American and European af Futurism and their influences on American vanguard movements ustic and literary trends; several Latin American veriollo and indigenous ideas to conceptualize a Latin American avant-garde. Thus, these movements shunned the colonial models that hinged upon the ideas, policies and fashions coming from the European Continent. 5

There were a variety of responses to Futurism in Latin America, both in its initial stages when the first translations of Marinetti's Foundation and Manifesto of Futurism appeared in El cojo ilustrarinetti's Foundation and 1909) and the literary magazine Revista de lustrado in Venezuela (15 May Honduras (15 Novem

Osorio: El futurismo y la vanguardia en América Latina, p. 41.

teenth century. It embraced Parnassianin poetic movement that began in the late ninmany references to mythology, free poetic form and esism and Symbolism and contained in Spean Modernism, although as a pan-Hispanic eroticism. It is not to be mistaken for links to It was a heterogeneous cultural force, consciouly $\mathrm{A}$ it also had repercussions links to French literature. Quoted in Osorio: El futuris

source is El universal (Caracas) y la vanguardia en América Latina, p. 33. The original are min explications, italics signal (11 September 1921). The terms in brackets are "Crine unless otherwise notgnal my emphasis. The translations throughout the pare "Criollos" are defined he noted.

at the top of the social here as the white descendants of the Spanish colonialists who were

une step down from those bic and racial hierarchies in the Spanish colonies (atro were Latin American nations. born on the European continent), and later, the indthough 
orhers returned to Futurism with a renewed interest. The art critic and historian Serge Fauchereau describes the general impact of the international movement on Latin America:

From Torres-Garcia to Siqueiros, many Latin Americans met in Spain, particularly Barcelona. Here the Uruguayan Barradas created Vibrationism, and Ultraism gained the active support of the Argentine Jorge Luis Borges and his siste Nora. When Borges returned to Argentina at the end of 1921 he introduced Ultraism there by publishing several manifestos, while the periodical Martin Twenties, there were signs of interest in Futurism in several Latin American countries, but the Futurist related movement that really triumphed was Mexican Stridentism

The history of Brazil's relationship with Futurism is more complicated. Although the first Futurist manifesto was published in Brazil in 1909, the same though he fist File the Brailie year as it appeared in Le Fignes it had Ronald de Carvalho, a contributor to the magazine Orfeu, introduced Pessoa, Sá Carneiro, Santa Rita, Almada-Negreiros and Portuguese Futurism to Brazil. Mario de Andrade (1893-1945) knew Soffici's books, but he was influenced by Verhaeren and the French avant-garde, as were all the Brazilian Modernists, writers and painters alike. At the end of 1921 Oswald de Andrade (1890-1954) witers an "Theoretical accomplished Futurism has just consigned Futurism to oblivion. "Theoretical, accomplished tus has died in Italy - it died a long time ago. Which is not to say that it was not responsible for a great artistic renewal, whose echoes have even reached Brazil.

Annateresa Fabris was more fatalistic than Fauchereau when she explained the situation in Brazil: "The first articles on Futurism were written by critics who did not support the new trend, and soon the adjective Futurist became a synonym for 'pathological', 'crazy', 'bizarre', 'strange."' In Hispanic America, the Nicaraguan poet Ruben Darío initially applauded Marinetti's poetry, but would ultimately disqualify the Futurist manifesto as being inútil (useless) and stated: "I don't believe that his manifesto will do more than encourage a good number of imitators to do 'Futurism' outand-out, many surely without having either the talent or the rhetoric of the initiator." This concern over pure and poor imitation on the part of Latin American artists with regard to European avant-garde movements was (and is still being) voiced as a matter of concern. Darío and other contemporaries respected Marinetti as a capable writer and artist, but they

Fauchereau: "Latin America", pp 499-500.

Fabris: "Brazil", pp. 437-438.

"No creo que su "No creo que su manifiesto haga más que ante sin a uner el talento ni el verbo de iniciador." Darí: "Ma a uril 1909, reprinted Darío: "Marinetti y el futurismo", La Nación (Buenos Aires), A Apric often saw Futurism's violence and dynamism as irreconcilable with Latin
American culture.

\section{The first news on Futurism in Venezuela}

This recoil from the avant-garde was especially true in Venezuela, where a semi-colonial society based upon the agricultural system of coffee and cacao plantations was still in place, and where a succession of coffee and ca(caudillos) stifled the country's intellectual development. Two important centres of study, the University of El Zulia in Maracaibo and important versity of Carabobo in Valencia, were shut down in 1904 by the caudillo Cipriano Castro (1899-1908). A few years later, Castro's successor Juan Vicente Gómez (1857-1935) closed the Central University of Venezuel Juan Caracas from 1912-1922. ${ }^{9}$ During the period of Gomecismo (1908-1935), seventy per cent of the Venezuelan population was still illiterate, and the cultural divide between the literate tryside grew. ${ }^{10}$ Within Caracas, however international publications such as Fantoctional and Fantoches, Billiken and Elite, among others, that catered for a small percentage of bourgeois readers who were perceptive of political and cultural events from around the world.

In the years 1909-1915, news related to Futurism and Marinetti's literary activities was published in Venezuela's leading literary journal, El cojo ilustrado (Caracas, 1892-1915). The editors tended to voice unfavourable comments, which is not surprising, given the magazine's unfavouraesthetic sympathies for Romanticism, European Modernism and especially Latin American modernismo. ${ }^{11}$ For example on 15 May and espeeditors wrote:

Marinetti with his rebel appearance can only make us smile. His doctrine is profoundly bourgeois, obsolete, reactionary, and instead of offering him the insult of believing in his convincingly presented inanities, we prefer to suppose that he has chosen the carnival period to dispatch a good joke.12

Ortega: La asociación general de estudiantes en Venezuela, p. 11

Pp. 383-38

2 "Marinetti con ilustrado en el centenario de su fundación 1892-1992, p. 6. de ces profundamente buroues obe menos qua hacernos sonreír. Su docencer en su convicción de epoca de carnaval para da semejantes pataratas preferimos suponer que ha escogido pp.283-284. 
In the same article, the magazine's editors parodied the Futurist manifesto by referring to an invented new movement called Energumerismo. ${ }^{13}$ The Energumerist Manifesto called for " 1 . [... the] radical destruction of the cosmos as it exists now; 2. [the] reconstitution of a new world without any preconceived plan (why are planets round instead of adopting the shape that each one of them would prefer?"14

This parody of the Futurist manifesto adopted the mantra of destruction and renewal in line with the radical spirit of the avant-garde, an aspect that Arturo Uslar Pietri and Mariano Picón Salas would eventually emulate. However, in the course of time, the news and comments related to Futurism in El cojo ilustrado changed from sarcastic comments to laudatory discourses. The issue of 1 June 1909 contained excerpts of the Foundation and Manifesto of Futurism as it appeared in Marinetti's journal Poesia, without any editorial interventions. ${ }^{15}$ In the issue of 15 July 1909 , in a brief note entitled "Un fiasco", the editors introduced and translated a review by the Belgian poet and critic André Fontainas of Marinetti's epic poem Conquest of the Stars (1902), which he deemed to be "full of obscurities" (lleno de obscuridades). He also made some scathing remarks on Marinetti's magazine Poesia and the performance of Marinetti's play Le Roi Bombance (published in 1905, performed in 1909), which he considered to be "deplorable" and "a great error of a true artist who could produce something much better". ${ }^{16}$ In the issue of 15 October 1909, the editors of El cojo ilustrado called Marinetti's magazine Poesia a "beautiful literary journal" (hermoso cuaderno periódico), stating that it is "truly magnificent" (verdaderamente magnífica) and "an intense effort of pure magnificent" (verdur so point of criticism reart" (un intenso esfuerzo de arte puro). Their sole point of cricism related to the lack of Spanish and Latin American authors represented in the journal. El cojo ilustrado, which introduced Venezuela to many international and national authors, reprimanded Marinetti's editorial policies because they did not have a sufficiently global scope and did not show enough fraternal sympathies with the literatures and poetic traditions of the Americas:

ine is a madman, a fanatic, a person possessed by the devil. 14 "1. [... La] destrucción radical del Cosmos tal como existe actualm qué los planetas sor titución de un mundo nuevo sin ningún plan preconcebido (¿po qué " El cojo illustrá ce ellos prefiera?)" El cojo ins 18:418 (15 May 1909), pp. 283-284.

18:418 (15 May 1909), pp. 283-284.

15 El cojo ilustrado 18:419 (1 June 1909), p. 312 .

16 "Es un formidable error de un verdadero art
It is time that our literature, which despite its initial stage of development i already so rich, be published and known throughout other romance-speaking com our problems so that thic sympathies, only hink of our problems so that they can show their dismay and hypocritical as tonishment and to say nonsense about our region. ${ }^{17}$

Elcojo ilustrado was perfectly entitled to say this, as this Venezuelan magazine did indeed possess a decidedly cosmopolitan attitude and translated works coming from Japan and Turkey as well as texts from more widely read (French, Spanish, German, Russian and Latin American) cultures.

Futurism made news again in El cojo ilustrado on 15 December 1912 when Jesús Semprúm wrote an unflattering remark on the release of Valentine Saint-Point's Manifesto of the Futurist Woman:

Many readers will remember Mr. Marinetti and his Futurist school that aroused the public's curiosity for some time. This was to be expected, as Mr. Marinet and his disciples and colleagues would proclaim a score of atrocities that which we are wont to consider as atrocities, as part of their aestheric least They glorified war, militarism, patriotism, anarchism, assassination and scorn for women. ${ }^{18}$

\section{Arturo Uslar Pietri and Mariano Picón Salas}

It was this focus on violence and misogyny that was to be replicated by authors such as Arturo Uslar Pietri (1906-2001) and Mariano Picón Sala (1901-1965), who embraced the innovatory force of the Futurist rhetoric and aesthetic and thus laid the foundation for a Venezuelan avant-garde. Picón Salas, at the age of sixteen, linked the necessity of war and literary renewal in a lecture given on 28 October 1917 at the Universidad de Los Andes in Merida, in which he stated: "War is necessary. It is necessary because when the effeminate young man from the city shoulders his bayonet and smells the smoke of the canons, he forgets the make-up that

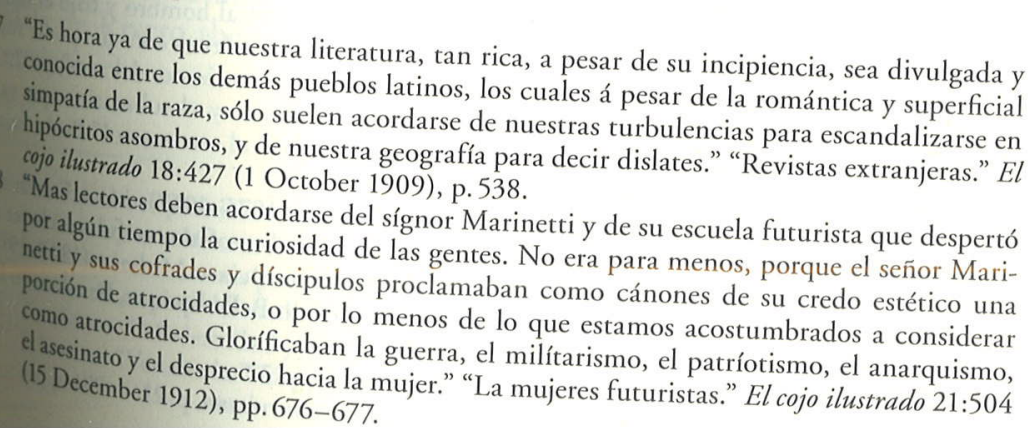
simparía de la los demás pueblos latinos, los cuales á pesar de la romántica y supugada y hipócrito la raza, sólo suelen acordarse de nuestras turbur de la romántica y superficial cojo ilustradombros, y de nuestra geografía para decir dislates." "Revistas extraizarse en "Mas lectores 18:427 (1 October 1909), p. 538.

por algín ti deben acordarse del sígnor Marinetti y de su escuela futurista que despof netti y sus tiempo la curiosidad de las gentes. No era para escuela futurista que despertó porción de cofrades y díscipulos proclamaban como cánonenos, porque el señor Maricomo atrecidrocidades, o por lo menos de lo que estamones de su credo estético una el asesinocidades. Gloríficaban la guerra el miliarastos estamos acostumbrados a considerar (15 Dece y el desprecio hacia la muje" "La . . December 1912), pp. 676-677. cojo ilustrado 18: 422 (15 July 1909), p. 396. 
reddens his cheeks and gives his eyes a violet hue". ${ }^{19}$ Picón Salas obviously had the Futurists in mind when he spoke of the "New Art" that "praises the smoke-emitting factory, the aeroplane that cuts through the air and the submarine that searches the depth of the waters for the siren's nest.,"20 As such, Picón Salas employed the Futurist rhetoric of macchinolatria (the veneration of the machine) and applauded the new technologies as an inspiration for the New Art that will displace the snobbism and exoticism of authors such as Claude Farrère and Octave Mirbeau. ${ }^{21}$ However, Picón Salas had to wait ten years before he could find in Uslar Pietri a counterpart ("un ejemplo equivalente"22). Uslar Pietri, like Picón Salas, would at times imitate the early Marinetti's love of war and scorn for women, promote aesthetic innovation and rebel against the past while embracing the new.

Gloria Videla de Rivero, the Argentinean scholar of the Latin American avant-garde, suggests in her Direcciones del vanguardismo hispanoamericano that the avant-garde had two tendencies: one was to rebel against tradition, the other to look towards the future:

The avant-garde has two faces, one that looks towards its immediate past - and Th - and through it to a tradition to break with it - in a rebellious attitude that is often aggressive, annoying, iconoclastic and destructive. It is no longer "normativity" that is the worst enemy - as it was for the Romantics - but rather certain ideals of the literary tradition: mimesis, symbolism, modernismo in the case of Latin America (aristocraticism, musicality, free form, lyricism, exoticism and - in genAmerica (aristocraticism, musicalic eral - themes and forms with poetic prestige). The other face of the avant-garde looks towards the future. It has been observed that the term "avant-garde" has a dynamic connotation. The vanguardists want to develop the future, inaugurate a new era, change rhythms, contribute to progress (formal investigations, experimentation, incorporation of new themes and anti-conventional flavours). ${ }^{23}$

The Venezuelan avant-garde worked in the same vein. Several writers and artists broke away from the aesthetics of exoticism, musicality and poetic

19 "La guerra es necesaria. Es necesaria, porque con la bayoneta al hombro y bajo el humo de los cañones, olvida el afeminado mozuelo de la ciudad los afeites con que ponla 57. en su cara y violetas en sus ojeras." Picón Salas: "Las nuevas corrientes del arte", p.

20 "Cantan la fabrica que humea, el aeroplano que viola el aire y el submarino que va á buscar en el fondo de la onda el nido de las sirenas. ¡Ese será el arte nuevo!" Picon Salse
"Las nuevas corrientes del arte", p. 58.

21 Claude Farrère, pseudonym of Frédéric-Charles Bargone (1876-1957), was a French a thor who served in the French colonies and wrote a number of successful novels set thor who served in the French colonies and wrote agasaki. Octave Mirbeau (1848-19n for exotic locations, such as Istanbul, Saigon, and Nagasaki. Octäe Epoque, best kn was a highly successful journalist and writer of the

his (politically and morally) scandalizing novels.

22 Osorio: El futurismo y la vanguardia en América Latina, p. 32
23 Videla de Rivero: Direcciones del vanguardismo hispanoamericano, p. 21. sophistication, as embraced by novelists such as Teresa de la Parra (18891936). ${ }^{24}$ The literary movement, Generación del 18 (Generation of 1918), prepared the ground for Uslar Pietri's forays, in 1927-1928, into Futurism, with the journals Indice and válvula. Members of founded the independent Círculo de Generación del 18 response to the Decadentism and modernismo Artes in Caracas in 1912, in responsed in the Academy of Fine Arts. Among them were Julio and Enrique Planchart, Fernando Paz Castillo and Rodolfo Moleiro. While some critics condemned members of this group for doing too little against the repressive political atmosphere in the country, others highlighted their contribution poltical atmosphere in modernismo to the avant-garde, ${ }^{25}$ calling them to the shift away from roup as well as the first post-modernismo group as well as the first pre-avant-garde group in Venezuela. ${ }^{26}$ As Jorge
Schwartz writes:

The first attempt to overcome Venezuelan modernismo occurs with the Generation of 1918 (José Antonio Ramos Sucre, Fernando Paz Castillo e Andrés Eloy Blace of a more audacious nature, begins with the publication, in 1925, of the magazine Élite, which counts amongst its collaboators young writers such as Arturo Uslar Pietri and Miguel Otero its collabohappened just before Arraíz's Áspero was published, a book of potry. This according to Enrique Anderson Imbert, "drew a dividi a book of poetry which, and 1928 generations". 27

As far as válvula was concerned, Uslar Pietri's main preoccupation centred on form rather than content. The magazine's focus on artistic renewal carried with it certain "growing pains": the artistic collective turned their back on the old and embraced the new : the artistic collective turned their as those of other avant-garde of nálvula as well how they should respond to Europs in Argentina and Chile wondered When, eventually, they artistic innovation. France, they did, they broke away from the cultural tutelage of Spain and France, they did so as members of new nations that were still in the process of developing a national identity and a consciousne still in the proAmericanness'. Thus of their 'Latin with it a desire to also fom the release from colonial fetters carried Videla de Rivero a modernism. American:

her identity as a Venezuet privilege, even as a woman in a field dominated by men, and aesthetics in her novels published criollo stock living abroad, to promulgate modernismo 6 Zasarte: "Los aires del cambio: Ii Paris (e.g., Ifigenia, 1924).

Schwartz: "Modernidad y vanguardia en poesura entre 1908 y 1935", pp. 390-391. cos, p. 185. "Venezuela." Vanguardas latino-americanas: Polêmicas, manifestos e textos criti- 
Our hypothesis is formed with regard to the relations between the American and European avant-gardes in a zone of critical-historiographical coincidences. We are convinced [...] of the otherness of Hispanic American literary creativity in comparison to European avant-garde literary movements. We consider that anytime there is artistic accomplishment (and not just a copy), American [artistic] expressions acquire different properties and conquer their own space in literary 列 American. ${ }^{28}$

\section{Uslar Pietri, Don Quixote and the hispanization} of Futurism in Indice

Arturo Uslar Pietri (1906-2001) was born into a middle-class family in Caracas and attended secondary school in Maracay, in the State of Aragua, where, at a young age, he began to publish his short stories. From 1923 to 1927, he collaborated with magazines such as Billiken, Élite and Caricaturas before starting válvula in 1928 with Miguel Otero Silva, Fernando Paz Castillo and Pedro Sotillo. Throughout his long life, this dedicated writer held many positions as literary critic and politician. He was a Senator of the Venezuelan Republic, a Minister of Education, a Minister of Domestic Affairs, Professor of Political Economy, a Presidential Candidate and the Permanent Venezuelan Ambassador to the UNESCO in Paris. For a short period, he was living in exile in New York, where he became Professor of period, he wa University. For fifty years (19481998), Uslar Pietri wrote the "Pizarron" column in the daily newspaper $E l$ nacional and set up two television programmes devoted to the humanities: "Valores humanos" and "Cuentame Venezuela." Among his most-known literary works are the novels Las lanzas coloradas (The Coloured Spears, (The Visit in Time, 1990; for which he won 1931), La wisita en el the the Rómulo Gallegos Prize), and the collection of essays, Las nubes (Thard Clouds, 1954). He was also the recipient of the Prince of Asturias award and the Grand Croix de la Légion d'Honneur. Hence, it is impossible to overestimate Uslar Pietri's imprint upon Venezuelan and world literature and culture.

Direciones del uanguardismo hispanoamericano, pp. 32-33.

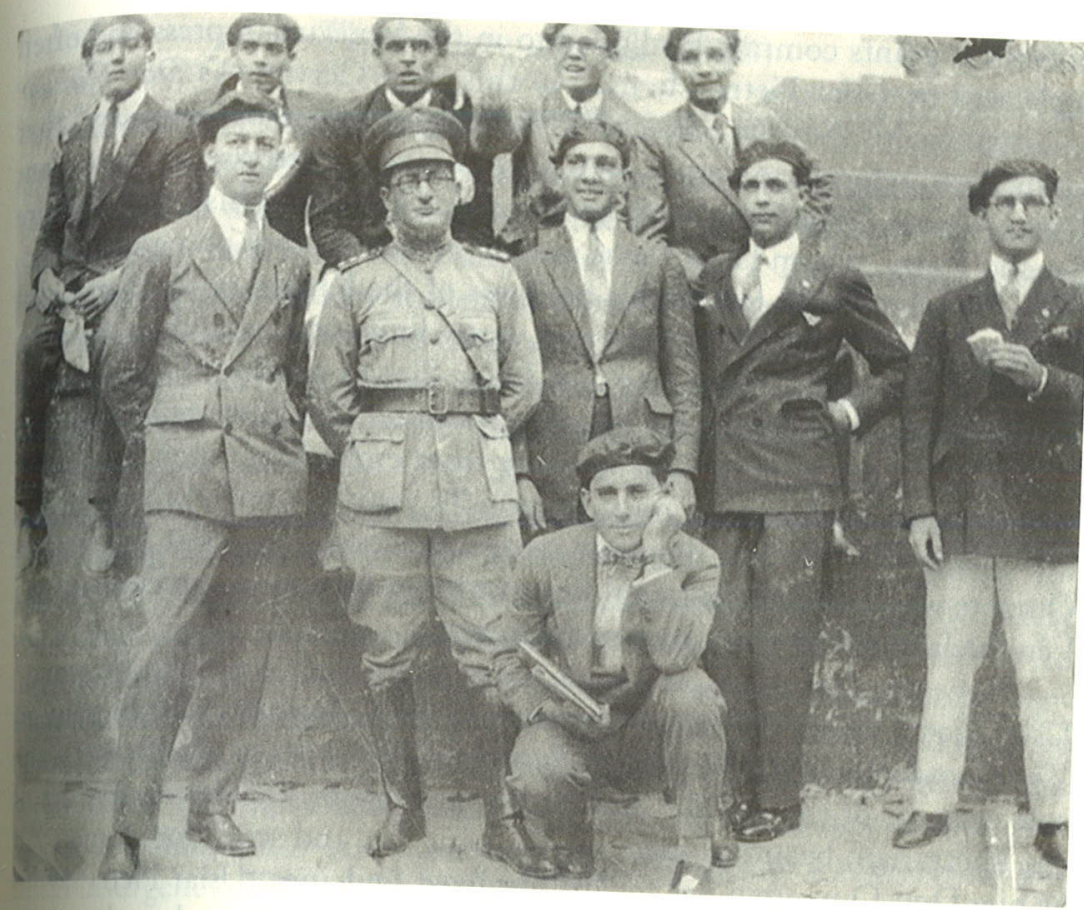

Fig.1: The Generación del 28. Uslar Pietri is fourth from the left (standing).

However, Uslar Pietri was only three-years old when the Foundation and Manifesto of Futurism was published on both sides of the Atlantic. As a young man, he observed the Futurist movement bourgeoning in Latin America and the responses it received in Venezuela, especially in Latin Marinetti's tour of South Americe, fived Venezuela, especially following included stopovers in Aires, ${ }^{29}$ As a etri addressed Funty-year-old member of the Seremos group, Uslar Pi1927 in the short-lived literary article called "El futurismo", published in Critica litert-lived literary magazine, Indice: Quincenario de combate. praised Marinetti's and loyally defended hesthetics, including his love of war and misogyny, centric". The Futurist him against the accusation of being "ridiculously ec.

p.213. The media attention Past': On the Reception and Impact of Futurism in Brazil", in Futurism, not just in the Surrounding Marinetti's tour sparked off a renewed interest 
polemical points commonly alluded to in the Venezuelan press and often replicated by Uslar Pietri. He used in this essay Cervantes's Don Quixote to hispanize his Futurist project. ${ }^{30}$ The "colossal purge of humanity" that Uslar Pietri referred to would even have come as a surprise to the valiant Don Quixote, "The Knight of the Sorrowful Face", and his trusted squire Sancho Panza, whom Uslar Pietri used to prove his point on natural selection: "Sancho would loathe this boldness of the Knight of the Sorrowful Face, who would take his shield and, ready for action, would go after the flights of this magnificent flag". In Uslar Pietri's reading, Don Quixote prevails in the end despite his manifest insanity. The illiterate fool Sancho Panza, who tries to stop Don Quixote from embarking upon his misadventures and misfortunes, must eventually vanish. Applied to Futurism, this means that war is a dynamic means of action. For Uslar Pietri, Don Quixote was an unconventional Futurist hero and a model to emulate in a Venezuela about to erupt into social unrest.

However, Don Quixote's romance would not sit well with the young Uslar Pietri, whose defence of Futurism copied Marinetti's ninth point in The Foundation and Manifesto of Futurism ("We wish to glorify war - the sole cleanser of the world - militarism, patriotism, the destructive act of the libertarian, beautiful ideas worth dying for, and scorn for women"31). While Don Quixote pines for his idealized Dulcinea, Uslar Pietri saw in women nothing but an anthropomorphic force that "throughout long centuries reeking of cemetery flowers" has chained men to a fatal course. In the present age, a woman is only a "complementary organ; if her physiological function ceases, she has no other function." 32 Hence, in the Indice essay, Uslar Pietri adopted Marinetti's early misogynist rhetoric and dice essay, Uslar Pietri an's s struggle against "la belleza-mujer" (beauty-woman). However, the Futurist concepts of audacity, courage and dynamism became key features of Uslar Pietri's propagation of Futurist aesthetics in the magazine titled válvula.

30 The four numbers of Indice can be found in the National Library in Venezuela. "El furuismo" appeared in Indice 1:1 (19 February 1927) and has been reprinted in Osorio- 40. nifiestos, proclamas y polemicas de 14

"Larinetio Critich tel 'gran claro de luna romántico que baña la faco burdel'" Uslar Pietri: "El futurismo", p. 239.
The review válvula (1928)

Válvula was published in January 1928, shortly before the Carnival week of 6-12 February 1928, when Students from the Universidad Central Venezuela had organized a march to the National Pantheon to honour the founding fathers of the Nation and to crown the Student Queen. However, a poem read by student and poet Pío Tamayo at the Carniva Queen's coronation, as well as other speeches, were judged by the police to be subversive. ${ }^{33}$ The government stopped all planned activities and thus caused massive student protests throughout the country - the first ever to take place in Venezuela. Over 200 students were detained; some were exiled and many were sent to forced-labour camps. In this situation of proliferating unrest, válvula was an appropriate ired by the Generación del 28. The mag lve' that sought to control an magazine served as an artistic 'safety valve' that sought to control an explosive situation, characterized by an overwhelming desire for both social and artistic reform. As such, the Venezuelan avant-garde developed in the midst of social unrest and massive demographic change and became a means for both aesthetic renewal and social reform. As Juan Carlos Santaella wrote: "As was to be expected, this literary rebellion - if it can be called that - emerged in a situation of political insurgency. This was the first time since Juan Vicente Gómez came to power that an iconoclastic movement would react against his terrible dictatorship." 34

In an editorial note published in the national newspaper, El universal that announced the publication of válvula, the anonymous reviewer expressed a sincere admiration for the journal, yet its authors were labelled "enter a journal, yet its authors were labelled "enthusiastic youth", "youngsters" similar to other "juvenile groups", and the magazine as a whole was characterized as a "juvenile publication" and editors and youth". Beside these references to the "youthfulness" of both editors and publication, attention was paid to their "noble" pursuit of "la belleza nueva", "lo bello" in "el arte nuevo" (the new beauty and beautifulness in the new a beautivoice to Venezuela's a part of a larger internatictic and literary vanguard, seen to be an integral thors of válvula foughtional avant-garde movement. In this sense, the aufor social justice fought not only against existing aesthetic forms, but also for social justice - and this at a time of turbulent student protests:

See also Raul Agudo Freites's Pio Tamayo y la vanguardia. la insurgen de esperarse, esta rebelión literaria - si se la pued

movimiencia política. Será esta la primera ve si se la puede llamar así - desembocará en Santaell to iconoclasta reaccionará conta desde su llegada al poder político, que un santaella: Manifiestos literarionará contra la dictadura del terrible Juan Vicente Gómez." 
The young members of válvula aspire towards form, alongside those courageous groups of young people in all of the civilized world's large cities who fight for the creation of an art form that responds to a modern sensibility of life. 35

Recently, Yolanda Segnini framed the vanguardism of the Generacion del 18 as a phenomenon that broke with previous literary currents, especially modernismo: "With the release of the single issue of válvula, the avant-garde received its definite and irreversible consecration as a literary movement." 36 She concludes that, despite the caudillismo of Juan Vicente Gómez, the history of periodicals in Venezuela during the age of Gomecismo reveals that Venezuela was not culturally isolated. Foreign writers and essayists regularly published in Venezuelan media and there was also a permanent exchange of journals and magazines. ${ }^{37}$ Moreover, if we examine válvula as an artistic expression of a Pan-American avant-garde, three key aspects emerge: 1) the movement was primarily fuelled by enthusiastic young authors and artists (muchachos); 2) the movement's members preoccupied themselves with reinventing aesthetic form; 3) the movement, while existing in its own specific tradition, aligned itself loosely with other similar-minded groups across Europe and Latin America.

This conflation of youthfulness, renovation and internationalism was characteristic of a variety of vanguard groups in Latin America and made them part of an international avant-garde alliance. In fact, the article written by Uslar Pietri for válvula, "Somos" (We Are), served as a manifesto that merged aesthetic renewal with social reform. Not only did the group aim to reinvent itself aesthetically through a break with outdated artistic schools, but it also expressed the need for a rupture with established social forms. Uslar Pietri and his friends rejected subtle nuances and semitones and instead preached the urgency of the scream and the efficiency of siand instead preached the urgency of the scream and the efficiency of si-

35 "Para cuantos solo aspiran a deleitarse en lo bello, a buscar las vivas manifestaciones del espiritu, la aparición de la simpática publicación juvenil no podra ser sino motivo de nober satisfacción. La parvada intelectual de Venezuela aspira a tener su vocero, su papel propio, en el cual ofrecemos sus producciones. Será por tanto, 'válvula' obra de juventud, a la que no se puede exigir obra perfecta, cuando la misma perfección sería, en caso tal, al lado inequivoco de limitación espiritual. Los muchachos de 'válvula' aspiran a formar al lado inequivoco de limitacion espiritual. de esos valioso grupos juveniles que en rodas día a la sensibilidad de la vida moderna. luchan por la creación de un arte que respondía a la lo bello y, en especial, por la beile nuestra sociedad hay una inexingible devoción por to bue la sana intelectualidad acoger que busca el arte nuevo, y [illegible] puez, es seguro quece. Saludamos cordialmente a 'válvula' con el entusiasmo y la estimación que se merece. Saludanta esfuerzo realiza juvenil publicación y le deseamos un éxito que corresponda al tenical 5 January 1928. para que 'válvula' saliera a la luz." "La revista 'válvula., El universal, 5 Ja p. 219.

36 Segnini: "Vi
37
Ibid., p. 227 with stark contrasts. Uslar Pietri promoted the discovery of a continent known primarily for its raw and unspoiled nature and turned this into a metaphor for the act of self-discovery. With audacity and faith, the válvulu group rejected the cosmopolitanism and Parnassian character of modern ismo and instead proclaimed the need to reinvent Venezuer of modern an eye towards internationalism, but also with a critical look at the very society they themselves were part of. Uslar Pietri emulated the genre of he literary manifesto (which was to become an important the genre of ezuelan cultural history) as well as the dy as well as the dynamism of Futurism to call for a long overdue social and artistic renewal. ${ }^{38}$ The manifesto reads:

We are a handful of young men with faith and hope, but without charity. We consider ourselves called to fulfil a great duty, suggested and laid down by ourselves: that of restoring and creating. Time will tell the validity of our work. We will work regardless of whether we will be understood or not! We know well that our efforts will be coupled with pain and for this we offer our young flesh.

We do not want to be classified according to schools or literary labels, nor will we permit this. We are of our time, and the world's heartbeat will be our guide. On the other hand, we have come to restore the true concept of a new art, already extremely abused by hypocrites and disfigured by untalented imitators, when not discredited by mannerisms that easily allow deserters and incompetent men to cut a fine figure.

The new art does not admit definitions because its liberty rebukes them, because it is never stationary in order to gain profile. The only idea capable of covering all "newisms" (literary, pictorial or musical), the only one, we repeat, is that of provoking new thoughts. The new art's ultimate purpose is to suggest, to say all with the least possible
amount of words (hence the need for metaphor and the double or age) or to say it in a highly condensed manner might flourish (with all attached possibilities) in so that the aesthetic ensemble rather than in the raw and limited instruments in soul to whom it is directed We aspire to an im and limited instruments of expression.

an intellectual. To a that will exceed or condense all that a treatise may say to an intellectual. To a canvas on which four brushstrokes capture more trans say to dence than all of the drawing manuals of the pompous schoos of transcenmusic in which one musical note encompasses the whole state of the past, to a In short, we aspire to give the masses their own tôle state of a soul

of art, so that the artwork may realize itself own rôle as collaborators of a work the instruments. artwork may realize itself in the soul with a totality denied by

We know thar tose has already been stated: To suggest.

already wielding one of its vicious ma tock us out, and for this purpose it is

spectable fighters, we like to concede

accept a priori that there is nothine the advantaged position to the enemy; we

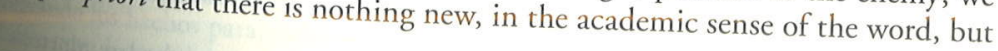

literarios" and Santeella's Maniffestas literantes's "Estética de la rebelión: Los manifiestos 
in return - and whoever dares to deny it? - there are a lot of virgin things under the sun that have never been contemplated: The possibility of discovery is still out there!

We detest all half-tones, all discretions; we only believe in the efficiency of silence or of a scream. válvula is the spout of a machine through which the explosive gas of the art of the future will escape. To begin with: we believe - that is already a force; we wait - that is a virtue, and we are ready to torture the seed already a force; we wait - that is a harvest is ours and we have the right seeds, for it when we want

We are a fistful of men, young and with faith, with hope, and without charity.39

\section{Conclusion}

The Venezuelan journal válvula was a project that expressed the desire of a small group of innovative and rebellious writers to promote a "new art" which expressed the spirit of the age, and in particular the creative potential of the Latin American people. In order to achieve this aim, they borrowed from devices and strategies developed by Futurist and other vanguard movements. These appropriations of the European avant-garde were not in the least imitative or plagiaristic. Uslar Pietri and his válvula group were innovative and original writers interacting with many like-minded artists around the globe. They possessed an internationalist outlook, yet at the same time they acted within the socio-historical context of 1920 s Venezuela, developing a form of Futurism that was designed to break the chains of caudillismo and to promote social reforms in urban centres. It is in this vein that Uslar Pietri developed his literary craft that operated with the power of suggestion, the poetic efficiency of metaphors, as well with the power of and image, all used towards the as with a conflation of the powers of word and image, all used towards the and social renewal.

Uslar Pietri and the members of the válvula group employed a hetrogeneous mixture of criollismo ${ }^{40}$ and Futurist-oriented aesthetics. Some of their contributions took the form of the manifesto, short stories such "Agua Sorda" (Deaf Water) by Carlos Eduardo Frías, "En el principio"

39 The translation again is mine. The original Spanish text can be found in Osorio's Mantfiestos, proclamas y polemicas de la vanguardia literaria hi.

Santaella's Manifestos literarios venezolanos, pp. America between the late nineteenth and

40 Criollismo was a literary movement in Latin America between the and types native to the early twentieth centuries that had a preoccupation with scen Europe, especially N Americas. It reacted against the influx of exotic idech
ism, Futurism, the glorification of speed and machines, etc.
In the Beginning) by Uslar Pietri and "Vástago" (Descendant) by José Salazar Dóminguez. ${ }^{41}$ Poems such as "30 y uno" (30 and One) by José Nucete-Sardi took the theme of the New Year's Eve to evoke the birth of he Future. Rafael Rivero employed Cubo-Futurist aesthetics in his cover design for válvula, using lower-case letters arranged diagonally across the page against a background of geometric shapes, as well as in his painting, La coupletista (The Cabaret Singer, c.1927) published in the magazine.

In conclusion, Uslar Pietri's turn to Futurism was a necessary step to further the process of artistic and social renewal that had already begun in Venezuela with groups such as the Generación del 18. Uslar Pietri's preoccupation with the particular American and Hispanic nature of artistic renewal made him identify with figures such as Don Quixote and, most importantly, would drive his later project of mestizaje (miscegenation) texts such as La creación del Nuevo Mundo (The Creation of the New World, 1990), which saw the originality and the inventiveness of Latin America as a pre-conditions for the creation and continuation of a particular New-World culture:

We are still searching for Amazons and Earthly paradises, accepting facts so that through them we may do what a distinguished Venezuelan said, recommend because he is still a highly rated master, namely Simón Rodre work who said: "Latin America is original, and that is why it should not bodríguez, And he added the phrase that I shall leave you with: "Fither we not be copied" we shall fail. ${ }^{42}$

\section{Bibliography}

igudo Freites, Raul: Pio Tamayo y la vanguardia. Caracas: Ediciones de la Biblioteca de la Universidad Central de Venezuela, 1969.

Anon]: "El futurismo." El cojo ilustrado, 1 June 1909: 312.

: "El futurismo de Marinetti." El cojo ilustrado, 15 May 1909: 283-84.

-: "La revista 'Valvula,." El universal, 5 January 1928.

-: "Un fiasco." El cojas." El cojo ilustrado, 1 October 1909: 538.

"El cojo ilustrado, 15 July 1909: 396

41. Pausides Silva: "De

p.421.

ceptando los hechos para, Amazonas y todavía estamos buscando Paraísos Terrenales Súre cuya lectura les recomiendo per elos, hacer lo que decía un venezolano

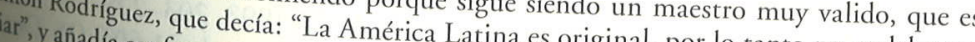
La creación desa frase que yo dejo con ustedes: "O inginal, por to tanto no se debe coación del Nuevo Mundo qejo con ustedes: "O inventamos, o erramos." Uslar Pietri: 
—: "Uslar Pietri, Arturo." Garrido Mezquita, ed.: Diccionario biográfico de Venezuela. Madrid: Talleres de Blass, 1953. 1185-1186.

Darío, Ruben: "Marinetti y el futurismo." Nelson Osorio Tejeda: El futurismo y vanguardia literaria en América Latina. Caracas: Centro de Estudios Latinoamericanos Rómulo Gallegos, 1982

El cojo ilustrado: En el centenario de su fundación 1892-1992. Exhibition catalogue Caracas: Biblioteca Nacional, Foro Libertador, 30 de noviembre de $1992-30$ de Caro de 1993. Caracas: Banco Maracaibo, 1992.

Fabris, Annateresa: "Brazil." Pontus Hulten, ed.: Futurism \&o Futurisms. New York: Abbeville Press, 1986. 437-438.

Fauchereau, Serge: "Latin America." Pontus Hulten, ed.: Futurism \&̊ Futurisms. New York: Abbeville Press, 1986. 499-500.

Gonzáles Silva, Pausides: "De 'La alborada' a 'Cantaclaro': Literatura y compromiso en cinco revistas." Carlos Pacheco, Luis Barrera Linares, and Beatriz Gonzále Stephan, eds.: Nación y literatura: Itinerario de la palabra escrita en la cultur venezolana. Caracas: Fundación Bigott, 2006. 415-429.

Infante, Ángel Gustavo: "Estética de la rebelión: Los manifiestos literarios." Carlos Pacheco, Luis Barrera Linares, and Beatriz González Stephan, eds.: Nación literatura: Itinerarios de la palabra escrita en la cultura venezolana. Caracas: Fu literatura: Itinerarios 407-413.

Lasare Valárcel, Javier: "Los aires del cambio: Literatura y cultura entre 1908 1935" Carlos Pacheco, Luis Barrera Linares, and Beatriz González Stephan, eds. Nación y literatura. Itinerarios de la palabra escrita en la cultura venezolan. Caracas: Fundación Bigott, 2006. 379-405.

Marinetti, Filippo Tommaso: Critical Writings. Ed. by Günter Berghaus. New York Farrar, Straus and Giroux, 2006.

Ortega, Wilmen: La asociación general de estudiantes en Venezuela. Caracas: Centro Nacional de Historia, 2009.

Osorio Tejed a Nelson: "Antecedentes de la vanguardia literaria en Venezuela (19091925)." Hispamérica 11:33 (1982): 3-30.

-. El futurismo y la vanguardia literario en América Latina. Caracas: Centro de Estudios Latinoamericanos Rómulo Gallegos, 1982.

- Manifiestos, proclamas y polémicas de la vanguardia literaria hispanoamericana. Caracas: Biblioteca Ayacucho, 1988.

Picón Salas, Marian: "Ias nuevas corrientes del arte." Nelson Osorio Tejeda, ed.: Manifiestos, proclamas y polémicas de la vanguardia literaria hispanoamericana. Caracas: Biblioteca Ayacucho, 1988. 50-59.

Rocha, João Cezar de Castro: "'Futures Past': On the Reception and Impact of Futurism in Brazil" Günter Berghaus, ed. International Futurism in Arts and Li turism in Brazil. Gutnter Ber. 2000. 204-221.

Caracas: Monte Ávila, 1992

Schwartz, Jorge, ed.: "Venezuela." Jorge Schwartz, ed.: Vanguardas latino-americanas: Polêmicas, manifestos e textos críticos. São Paulo: Editora da Universida de São Paolo, 1995. 185-187.

Segnini, Yolanda: "Vida intelectual y gomecismo." Elías Pino Iturrieta, cd.. J Vicente Gómez y su época. Caracas: Monte Avila, 1993. 203-229. (15 Decembe

Semprúm, Jesús: "Las mujeres futuristas." El cojo ilustrado 21.504 (15 De 1912): 676-677.
Silva, Pausides Gonzáles: "De 'La alborada' a ‘Cantaclaro': Literatura y compromiso en cinco revistas." Carlos Pacheco, Luis Barrera Linares, and Beatriz González Stephan, eds.: Nación y literatura: Itinerarios de la palabra escrita en González venezolana. Caracas: Fundación Bigott, 2006. 415-29.

Uslar Pietri, Arturo: La creación del Nuevo Mundo. Caracas: Grijalbo, 1992.

: "El futurismo." Indice 1:1 (19 February 1927): s.p.

: "Sómos." Válvula, January 1928. s.p.

Videla de Rivero, Gloria: Direcciones del vanguardismo hispanoamericano. Vol. 2. Mendoza: Universidad Nacional de Cuyo, Facultad de Filosofía y Letras, 1990. Zambrano, Gregory: "Modernidad y vanguardia en la poesia venezolana de los año veinte." Carmen Díaz Orozco, et al.: Modernidad y alteridades: Antología de trabajos de grado de la Maestría en Literatura Iberoamericana. Mérida: Universidad de los Andes, Facultad de Humanidades y Educación, Instituto de Investigaciones Literarias "Gonzalo Picón Febres", Maestría en Literatura Iberoamerican1999. 71-105. 